ROCZNIKI PEDAGOGICZNE

Tom 11(47), numer 2 - 2019

DOI: http://dx.doi.org/10.18290/rped.2019.11.2-11

STANISŁAWA NAZARUK

EWA TOKAREWICZ

ANNA KLIM-KLIMASZEWSKA

\title{
POZIOM ROZWOJU GRAFOMOTORYCZNEGO U DZIECI 5-LETNICH W ASPEKCIE GOTOWOŚCI DO PODJĘCIA NAUKI PISANIA
}

\author{
WPROWADZENIE
}

Powszechnie wiadomo, że wszechstronny rozwój dziecka, to nie tylko poszerzanie jego wiedzy i umiejętności, ale również kształcenie i wyrabianie sprawności ruchowej. Paul Dennison stwierdził, iż „ruch jest drzwiami uczenia się”. Wykorzystując swoje wieloletnie badania i obserwacje zauważył, że poruszając się w sposób zorganizowany można doprowadzić do pełnej aktywizacji i integracji mózgu (Dennison, Dennison, 2003). Dzieci sprawne ruchowo mają dobre samopoczucie, poprzez aktywność ruchową potrafią się zrelaksować, często korzystają z pobytu na świeżym powietrzu, są więc dotlenione, a tym samym mają wypoczęty mózg, który chłonie wiedzę. Natomiast dzieci mało sprawne ruchowo są kapryśne, rozdrażnione i smutne. Często też są odrzucane przez rówieśników, jako mało atrakcyjni partnerzy do gier i zabaw (Szymańska, 2004). Sprawność ruchowa ma także wpływ na motorykę małą, czyli sprawność dłoni i palców, co jest niezmiernie ważne w nauce pisania. Motoryka mała rozwija się wraz z wiekiem. Dlatego przygotowanie dziecka do nauki pisania jest procesem długotrwałym i jednocześnie złożonym, składającym się z wielu

Dr StanisŁawa Nazaruk - Państwowa Szkoła Wyższa im. Papieża Jana Pawła II w Białej Podlaskiej Wydział Nauk o Zdrowiu i Nauk Społecznych; e-mail:stnazaruk@ poczta.onet.pl

Mgr Ewa Tokarewicz - Państwowa Szkoła Wyższa im. Papieża Jana Pawła II w Białej Podlaskiej Wydział Nauk o Zdrowiu i Nauk Społecznych; e-mail: e.tokarewicz@ dydaktyka.pswbp.pl

Prof. nzw. dr hab. AnNA KLIM-KlimaszewsKA - Uniwersytet Przyrodniczo-Humanistyczny w Siedlcach, Wydział Humanistyczny; e-mail: anna.klim-klimaszewska@uph.edu.pl 
etapów, a na jego prawidłowy przebieg wpływają różne czynniki związane z rozwojem dziecka i wychowaniem.

\section{ISTOTA ROZWOJU GRAFOMOTORYCZNEGO}

Rozwój grafomotoryczny dziecka jest stosunkowo nowym pojęciem, odnoszącym się do wykształcenia umiejętności odtwarzania znaków graficznych (np. liter), w określonym miejscu na powierzchni kartki. Ogólnie rzecz ujmując grafika - to zapis (gr. grapho - piszę, rysuję), motoryka - to zdolność do wykonywania różnych czynności ruchowych (Bogdanowicz, 2009; Szymańska, 2004; Przewęda, 1981).

Proces pisania to bardzo trudna sztuka wymagająca wielu skomplikowanych czynności psychomotorycznych: umiejętności przeprowadzenia analizy dźwiękowej zapisanego słowa, kojarzenia wyobrażeń liter z ruchami ręki, współpracy analizatorów wzrokowego i kinestetyczno-ruchowego. W procesie pisania dziecko musi prawidłowo spostrzegać oraz zapamiętywać graficzny obraz poszczególnych liter. Powinno rozpoznawać dźwięki wchodzące w skład wyrazu, podporządkowywać im odpowiednie znaki graficzne i w należytej kolejności je zapisać. Dlatego też proces pisania wymaga odpowiednio sprawnej ręki, bo to za jej pomocą dziecko przenosi na papier wzrokowe wyobrażenie litery (Klim-Klimaszewska, 2015, Bogdanowicz, 2009; Sawa, 1980).

Jednym z elementów oceny poziomu pisania jest ocena strony graficznej pisma. Obejmuje ona technikę, płynność, tempo pisania i estetykę pisma. Zdarza się, że u niektórych dzieci mogą występować trudności w opanowaniu umiejętności pisania. Trudności te mogą polegać nie tylko na braku precyzji ruchów dłoni i palców, lecz także na zbyt wolnym tempie pisania, wadliwej regulacji napięcia mięśniowego. Zaburzenia rozwoju psychoruchowego, przejawiające się małą sprawnością motoryczną ręki i nieprawidłową koordynacją wzrokowo-ruchową, których symptomami są specyficzne trudności w procesie nabywania umiejętności wyraźnego i czytelnego pisania, określa się pojęciem dysgrafii (Bogdanowicz, 2009; Krasowicz-Kupis, 2009).

Edyta Gruszczyk-Kolczyńska i Ewa Zielińska uważają, że ćwiczenia grafomotoryczne, bezpośrednio przygotowujące do nauki pisania, należy organizować na pół roku przed rozpoczęciem przez dzieci nauki szkolnej. Ćwiczenia te mają być poprzedzone różnymi zabawami i ćwiczeniami rozwijającymi koordynację wzrokowo-ruchową oraz sprawność manualną dzieci, takimi jak: zabawy 
kształtujące płynność ruchów obu ramion, zabawy wspierające koordynację ruchów zmiennych obu ramion, rysowanie obrazków na asfalcie, zabawy ruchowo-graficzne, w których dziecko odwzorowuje ślad swojego biegu, skoków, przebytą przez siebie drogę, gry planszowe rysowane na asfalcie lub ubitej ziemi, układanki według wzoru, konstruowanie ludzików z warzyw oraz kasztanów i żołędzi, lepienie z plasteliny i masy solnej, sklejanie modeli i wiązanie węzłów marynarskich, darcie i wydzieranie z papieru, wycinanie nie tylko wzdłuż narysowanych linii, rysowanie szlaczków i rozet, układanie patyczków i rysowanie ich na papierze w kratkę, zagadki pantomimiczne, w których dzieci mają za zadanie uświadomić sobie kolejność wykonywanych czynności (Gruszczyk-Kolczyńska, Zielińska, 2009).

Pomimo tego, iż przedstawione sposoby pracy z dzieckiem przygotowującym się do nauki pisania dzieli ponad dwadzieścia lat, biorąc pod uwagę ich czas opublikowania, to sposoby pracy obecnie są bardzo podobne, ponieważ zwracają uwagę na stymulowanie ogólnego rozwoju organizmu, na usprawnienie u dziecka koordynacji wzrokowo-ruchowej, na usprawnienie mięśni palców i współpracy obu rąk, na wdrażanie do dokładności, staranności, na rozwijanie wrażliwości estetycznej, z jednoczesnym wzmacnianiem cech osobowości, a tym samym wyrabianiem właściwej motywacji do nauki.

O tym, że dziecko jest gotowe do podjęcia nauki pisania mówimy wówczas, gdy pod względem dojrzałości w rozwoju motorycznym występuje: koordynacja ruchów ramienia, przedramienia, nadgarstka, dłoni, palców w procesie odtwarzania znaków graficznych (koordynacja w zakresie małej i dużej motoryki), szybkość odtwarzania, czyli tempo pracy (Przewęda, 1981).

W rezultacie, dzięki dobrze skoordynowanym ruchom, dziecko potrafi kreślić znaki graficzne linią ciągłą, swobodnymi ruchami, bez zbędnego napięcia mięśni i stawów. Nie zrobi tego jednak, gdy w jego rozwoju intelektualno-motorycznym nie wystąpi:

- umiejętność spostrzegania analityczno-reprodukcyjnego, dzięki któremu dziecko rozpoznaje, porównuje i odtwarza znaki graficzne, uwzględnia ich elementy składowe, położenie, kierunek, wymiary i łączenia liniowe;

- umiejętność przetwarzania obrazu graficznego na obraz ruchu dynamicznego;

- taki stopień orientacji przestrzennej, która umożliwi odtwarzanie znaków graficznych, w określonym miejscu na powierzchni kartki, z zachowaniem kierunku pisania od lewej do prawej oraz następstw równoległych linii (Dziamska, 2005).

W przygotowaniu do nauki pisania, oprócz umiejętności grafomotorycznych, istotne znaczenie przypisuje się gotowości pod względem emocjonalno-społecznym, 
dzięki której dziecko będzie posiadać gotowość do najlepszego wywiązania się z zadania postawionego przez osobę dorosłą, będzie wytrwałe i gotowe do pokonania trudności, będzie posiadało zdolność do samokontroli i krytycznej oceny własnego wytworu (Przewęda, 1981; Dziamska, 2005).

Placówki przedszkolne, zgodnie z aktualną podstawą programową, mają przygotować dziecko, między innymi, do podjęcia przez nie nauki pisania. Przygotowanie to koncentruje się głównie na rozwijaniu sprawności psychomotorycznych (Dz. U. z dn. 24.02.2017 r., poz. 356). W tym miejscu należy zwrócić uwagę na prawidłowości rozwoju motorycznego dziecka, które są kompatybilne z grafomotoryką. Kazimiera Wlaźnik postrzega rozwój motoryczny jako szereg dokonujących się zmian jakościowych i ilościowych, przy czym w aspekcie jakościowym bierze się pod uwagę umiejętności ruchowe oraz sposoby wykonywania różnych ruchowych czynności. Natomiast w aspekcie ilościowym uwzględnia się stopień opanowania i sposób wykonywania ruchu, czyli sprawność ruchową, która uzależniona jest od poziomu rozwoju tak zwanych cech motorycznych, do których zalicza się: siłę, szybkość, zręczność, zwinność, wytrzymałość, gibkość oraz moc (Wlaźnik, 1996).

Marta Bogdanowicz zwraca uwagę, że w pierwszych okresach rozwoju motorycznego u dziecka wyraźnie można zaobserwować jego wielki wysiłek włożony w ruch oraz nadmierne napięcie mięśniowe, które nazywa hipertonią, polegającą na przewadze pobudzania nad hamowaniem w ośrodkach nerwowych. Stopniowo, w miarę rozwoju dziecka, ulega to zmianie, by około osiemnastego miesiąca życia pojawiło się napięcie obniżone, które wkrótce podnosi się, uzyskując stan równowagi (Bogdanowicz, 2009; Brzezińska, 2004).

Inną znamienną cechą sprawiającą, że rozwój motoryczny przebiega szybciej i wszechstronniej, jest uzewnętrzniona przez dziecko radość z działania, gdyż w wieku poniemowlęcym i przedszkolnym jest ono prawie bez przerwy w ruchu. Ważnym w tym okresie zadaniem dla otoczenia jest zadbać o to, aby ten głód ruchu zaspokoić i otoczyć dziecko atmosferą zainteresowania, miłości oraz współdziałania w próbach usamodzielnienia się. Koniec wieku poniemowlęcego i początek przedszkolnego charakteryzuje się tym, że dziecko w swoich ruchach coraz bardziej przypomina człowieka dorosłego. Tak samo jak on porusza się, posługując się dwunożnym chodem, jednak stąpa na całych stopach, a chodzenie jest niezgrabne, pozbawione elastyczności i zakłócone nawet niewielkimi przeszkodami. Największe różnice zauważa się, gdy dziecko porusza się po schodach, przemieszczając się po nich krokiem dostawnym, również jego chwyty i inne ruchy są jeszcze niedoskonałe, pomimo że już przyswojone. Na przełomie 
pierwszego i drugiego roku życia przejawy lateralizacji często słabną, gdyż chód dziecka angażuje w jednakowym stopniu obie nogi, a tym samym obie półkule mózgowe (Bogdanowicz, 2009; Cyran-Prus, Matych, 2004).

Istotna zmiana w ogólnej sprawności ruchowej, zręczności i precyzji w działaniach manualnych następuje u dzieci na przełomie 4 i 5 roku życia. Zmiany, dokonujące się w tym okresie, mają charakter skoku rozwojowego (Bogdanowicz, 2009; Brzezińska, 2004). Dzieci 5-letnie mają już opanowanych wiele czynności wymagających precyzji ruchów. Potrafią same siebie obsługiwać, wykonują szereg prac użytecznych, łączą kilka czynności razem, na przykład rzut z chwytem, podnoszenie przedmiotu $\mathrm{w}$ staniu na jednej nodze itp. Ich koordynacja wzrokowo-ruchowa ulega znacznemu rozwojowi, wzrasta pamięć ruchowa, co wpływa na ich orientację $\mathrm{w}$ przestrzeni. Dzięki niej ich ruchy stają się pewniejsze, bardziej zdecydowane, szybsze. Pomimo iż ich procesy pobudzania mają przewagę nad hamowaniem, wyraźnie zaznacza się ich wysiłek nad opanowaniem własnej ruchliwości. Należy mieć na uwadze, że jest to okres biologicznej potrzeby ruchu, który objawia się ogromną ruchliwością dzieci, co jednocześnie stanowi stymulator rozwojowy dla ich organizmu, wzbogacający je w umiejętności i doświadczenia motoryczne (Brzezińska, 2004; Mańkowska, 2005).

W końcowym okresie wieku przedszkolnego dzieci 6-letnie wykazują wysoki poziom zręczności, płynności i elastyczności motorycznej, przy czym najszybciej rozwija się zwinność, a najwolniej siła. Wiele ruchów ulega automatyzacji, co uwidacznia się w ich harmonijnym wykonaniu. Wielokrotność doświadczeń ruchowych przejawia się $\mathrm{w}$ antycypacji ruchowej, czyli przewidywaniu, celowości ruchów, kiedy to dziecko przystosowuje pozycję ciała i ustawienie ręki do czynności, która ma nastąpić (Dmochowska, 1991). W tym okresie wzrasta wyraźnie sprawność manualna rąk, przejawiająca się między innymi precyzją w rysowaniu szczegółów, dokładnością w wykonywaniu skomplikowanych czynności rąk. Wiele z nich potrafią już wykonać bez kontroli wzroku, mają opanowany cały szereg schematów ruchowych, w których płynnie łączą kolejne czynności. W tym wieku w większości przypadków ustala się też lateralizacja (Cyran-Prus, Matych, 2004). Sześciolatki zaczynają zwracać uwagę na jakość wykonywanych ruchów, pojawia się współzawodnictwo, gdzie zachodzi możliwość porównywania siebie $\mathrm{z}$ innymi. W kształtowaniu ich motoryczności dominują wzorce społeczne czerpane z najbliższego otoczenia (rodzina, koledzy z podwórka czy przedszkola) (Dmochowska, 1991).

Mając na uwadze prawidłowy rozwój dziecka w aspekcie gotowości szkolnej, w której między innymi szczególną uwagę zwraca się na umiejętności 
grafomotoryczne dziecka, czyli na przygotowanie do nauki pisania, przeprowadzono badania, których główny problem przedstawiono w formie pytania: Jaki poziom rozwoju grafomotorycznego charakteryzuje dzieci 5-letnie uczęszczające do przedszkoli? Problem główny uszczegółowiono w trzech dodatkowych pytaniach:

1. Czy umiejętności grafomotoryczne badanych dzieci znajdują się w normie?

2. Jakie umiejętności grafomotoryczne dzieci rozwijają najszybciej?

3. Rozwój jakich umiejętności grafomotorycznych będzie wymagał dodatkowych ćwiczeń i pomocy ze strony nauczycieli oraz rodziców dzieci?

\section{ZAŁOŻENIA METODOLOGICZNE BADAŃ}

Podjęte badania wpisują się w badania z pedagogiki przedszkolnej. Zostały one przeprowadzone $\mathrm{w}$ jednym niepublicznym $\mathrm{i}$ w trzech samorządowych przedszkolach zlokalizowanych na terenie miasta Biała Podlaska. Wybór metod badawczych uwzględniał przede wszystkim postawione problemy badań. Do diagnozy poziomu umiejętności grafomotorycznych dzieci w wieku 5 lat zastosowano test autorstwa N.I. Oziereckiego, przystosowany do polskich potrzeb przez Aleksandra Barańskiego (Putyński, 1998). Sześć ćwiczeń w teście Oziereckiego obrazuje różne objawy koordynacji nerwowo-mięśniowej, a więc przy ich zastosowaniu można ocenić podstawowy mechanizm pojętności i sprawności ruchowej: I grupa - równowaga i koordynacja statyczna; II grupa - koordynacja ruchów rąk; III grupa - koordynacja ruchów ciała; IV grupa - zdolność do wykonywania ruchów szybkich; V grupa - zdolność do wykonywania różnych ruchów jednocześnie, na przykład inne ruchy nogami, a inne rękami; VI grupa precyzja ruchów i zdolność koncentrowania się wyłącznie na czynnościach zadanych, co ocenia się faktem występowania lub niewystępowania przyruchów (synkinezji) (Putyński, 1998).

Każde dziecko, uczestniczące w badaniach, otrzymało do wykonania jedno ćwiczenie z każdej z sześciu grup, odpowiednie dla jego wieku. Jeżeli je poprawnie wykonało, otrzymało następne z tej samej grupy, lecz przeznaczone dla dzieci o rok starszych. Jeśli nie potrafiło poprawnie wykonać, otrzymało ćwiczenie z tej samej grupy, lecz przeznaczone dla dzieci o rok młodszych. W ten sposób, zgodnie z założeniami wymienionego testu, ustala się w każdej grupie ćwiczeń, jak trudne zadanie ruchowe badany potrafi wykonać, przy czym trudność wyrażona jest tu miarą wieku. Badania przeprowadzono w roku szkolnym 2016/2017 w dwóch etapach. Pierwszy etap zrealizowano w październiku 2016 roku, a drugi w maju 2017 roku. 


\section{UCZESTNICY BADAŃ}

Podstawowe dane placówek przedszkolnych wraz z liczbą dzieci w wieku 5-lat biorących udział w badaniach przedstawiono w tabeli 1 .

Tabela 1. Podstawowe dane dzieci i placówek przedszkolnych

\begin{tabular}{|l|l|l|c|c|}
\hline \multirow{2}{*}{ Lp. } & \multicolumn{1}{|c|}{ Nazwa placówki przedszkolnej } & \multicolumn{1}{c|}{ Lokalizacja } & \multicolumn{2}{|c|}{ Dzieci } \\
\cline { 3 - 5 } & & & $\mathrm{N}$ & $\%$ \\
\hline 1. & Przedszkole Samorządowe Nr 15 & miasto Biała Podlaska & 34 & 28,3 \\
\hline 2. & Przedszkole Samorządowe Nr 11 & miasto Biała Podlaska & 22 & 18,3 \\
\hline 3. & Przedszkole Samorządowe Nr 13 & miasto Biała Podlaska & 36 & 30,0 \\
\hline 4. & $\begin{array}{l}\text { Niepubliczne Przedszkole im. Przyjaciół } \\
\text { Kubusia Puchatka }\end{array}$ & miasto Biała Podlaska & 28 & 23,4 \\
\hline Ogółem & & 120 & 100,0 \\
\hline
\end{tabular}

Wszystkie dzieci uczestniczące $\mathrm{w}$ badaniu urodziły się w tym samym roku kalendarzowym. Natomiast $\mathrm{w}$ tabeli nie ma podziału na płeć. Wynika to z zaleceń stosowania testu. Autor wymienionego narzędzia badawczego zaznaczył, że dopiero od 9 roku życia dziecka można w badaniach uwzględniać płeć.

Wyniki dzieci z wykonanych ćwiczeń z I grupy, sprawdzających równowagę i koordynację statyczną, przedstawiono w tabeli 2. Podczas badania dzieci miały przyjąć postawę równoważną w wysokim wspięciu i mając otwarte oczy wytrzymać w takiej pozycji 10 sekund. Analizując wyniki (tabela 2) widać, że w pierwszym etapie badań (realizacja październik 2017) 70,8\% dzieci z badanej grupy wykazuje wyniki w normie rozwojowej, zaś $29,2 \%$ wykazuje opóźnienie roczne. Drugi etap badań wykonano w tej samej grupie dzieci po sześciu miesiącach i wyniki zestawiono $\mathrm{w}$ trzeciej kolumnie tabeli 2. Ponowne sprawdzenie równowagi podczas drugiego badania wykazało, że poziom koordynacji statycznej na poziomie normy wykazuje 79,2\% dzieci, zaś roczne opóźnienie w dalszym ciągu stwierdzono u $20,8 \%$ badanych. 
Tabela 2. Wyniki badania poziomu równowagi i koordynacji statycznej

\begin{tabular}{|l|c|c|}
\hline \multirow{2}{*}{$\begin{array}{l}\text { Koordynacja statyczna } \\
\text { i równowaga }\end{array}$} & Badanie I & Badanie II \\
\cline { 2 - 3 } & $\%$ & 79,2 \\
\hline Norma & 70,8 & 20,8 \\
\hline Opóźnienie roczne & 29,2 & 100,0 \\
\hline
\end{tabular}

Wyniki z drugiej grupy ćwiczeń, które służyły sprawdzeniu koordynacji ruchów ręki prawej i lewej przeprowadzone w I i II badaniu zestawiono w tabeli 3. Wymieniony poziom koordynacji był sprawdzany poprzez mierzenie czasu potrzebnego dziecku na zmięcie serwetki o wymiarach $5 \mathrm{~cm} \times 5 \mathrm{~cm}$ - prawą ręką (limit czasu to15 sekund). W badaniu pierwszym normą rozwojową wykazało się $79,1 \%$ dzieci, opóźnieniem rocznym - 12,5\% dzieci. Stwierdzono także przyspieszenie roczne u $4,2 \%$ dzieci, a nawet przyspieszenie dwuletnie u 4,2\% dzieci. Podczas badania drugiego przyspieszenie dwuletnie stwierdzono u $2,8 \%$, a roczne przyspieszenie u $41,7 \%$, zaś normę rozwojową u $50 \%$ badanych. U żadnego z badanych dzieci nie stwierdzono opóźnień.

Tabela 3. Poziom koordynacji ruchów rąk- ręka prawa i lewa

\begin{tabular}{|l|c|c|c|c|}
\hline \multirow{2}{*}{ Koordynacja ruchów rąk } & \multicolumn{2}{|c|}{ Ręka prawa } & \multicolumn{2}{c|}{ Ręka lewa } \\
\cline { 2 - 5 } & Badanie I & Badanie II & Badanie I & Badanie II \\
\cline { 2 - 5 } & $\%$ & $\%$ & $\%$ & $\%$ \\
\hline Norma & 79,1 & 50,0 & 83,3 & 70,8 \\
\hline Opóźnienie roczne & 12,5 & - & 8,3 & - \\
\hline Przyspieszenie roczne & 4,2 & 41,7 & 8,4 & 29,2 \\
\hline Przyspieszenie dwuletnie & 4,2 & 8,3 & - & - \\
\hline Ogółem & 100,0 & 100,0 & 100,0 & 100,0 \\
\hline
\end{tabular}

Poziom koordynacji ruchów rąk, w obrębie ręki lewej sprawdzono poprzez mierzenie czasu potrzebnego dziecku na zmięcie serwetki o wymiarach $5 \mathrm{~cm}$ x $5 \mathrm{~cm}$ - lewą ręką (limit czasowy to 20 sekund). Analiza danych w tabeli 3 pokazuje, że podczas badania pierwszego normą wykazało się 83,3\% dzieci, opóźnieniem 
rocznym - 8,3\% dzieci. Stwierdzono także przyspieszenie roczne u 8,3\% badanych. W drugim badaniu koordynację w zakresie normy wykazało 70,8\% badanych, przyspieszenie roczne $29,2 \%$, opóźnienia nie stwierdzono.

Wyniki dzieci z wykonania ćwiczeń z III grupy zamieszczono w tabeli 4 . W badaniu pierwszym sprawdzano koordynację ruchów całego ciała poprzez wykonywanie podskoków na prawej nodze wzdłuż linii o długości $5 \mathrm{~m}$. Podczas podskoków dziecko nie mogło zboczyć z linii więcej niż o $5 \mathrm{~cm}$. Taką umiejętnością wykazało się 75\% dzieci, natomiast mających trudność z trzymaniem się linii, czyli roczne opóźnienie, wykazało $16,7 \%$ badanych. $8,3 \%$ dzieci wykazało się rocznym przyspieszeniem. W badaniu II normę rozwojową stwierdzono u 58,3\% badanych, roczne opóźnienie u 4,2\%, roczne przyspieszenie u 37,5\% dzieci.

Analizując wyniki dzieci, uzyskane podczas podskoków wzdłuż linii na lewej nodze, przedstawione w tabeli 4 widać, że w normie znajduje się $66,7 \%$ dzieci, roczne opóźnienie zauważono u $25 \%$, zaś przyspieszenie u $8,3 \%$. W II badaniu dzieci uzyskały następujące wyniki: w normie $-50 \%$, roczne opóźnienie $-16,7 \%$, roczne przyspieszenie $-33,3 \%$.

Tabela 4. Poziom koordynacji ruchów całego ciała - noga prawa i lewa

\begin{tabular}{|l|c|c|c|c|}
\hline \multirow{2}{*}{ Koordynacja ruchów całego ciała } & \multicolumn{2}{|c|}{ Noga prawa } & \multicolumn{2}{c|}{ Noga lewa } \\
\cline { 2 - 5 } & Badanie I & Badanie II & Badanie I & Badanie II \\
\cline { 2 - 5 } & $\%$ & $\%$ & $\%$ & $\%$ \\
\hline Norma & 75,0 & 58,3 & 66,7 & 50,0 \\
\hline Opóźnienie roczne & 16,7 & 4,2 & 25,0 & 16,7 \\
\hline Przyspieszenie roczne & 8,3 & 37,5 & 8,3 & 33,3 \\
\hline Ogółem & 100,0 & 100,0 & 100,0 & 100,0 \\
\hline
\end{tabular}

Kolejnym zadaniem z grupy czwartej ćwiczeń, badającym zdolność dzieci do wykonywania ruchów szybkich, było nawijanie nitki o długości 2 m na motek. Limit czasowy dla ręki prawej wynosił 12 sekund, a dla ręki lewej - 18 sekund. Tabela 5 przedstawia uzyskane wyniki. Dzieci, które poradziły sobie z tą próbą mieszcząc się w normie, było $83,3 \%$, dzieci z opóźnieniem rocznym było $16,7 \%$. Dzieci z przyspieszeniem rocznym nie stwierdzono. W II badaniu uzyskano wyniki: w normie zmieściło się 83,3\% dzieci, opóźnienie roczne stwierdzono u 4,2\%, przyspieszenie u $12,5 \%$ badanych dzieci. 
Tabela 5. Zdolność do wykonywania ruchów szybkich - ręka prawa i lewa

\begin{tabular}{|l|c|c|c|c|}
\hline \multirow{2}{*}{$\begin{array}{l}\text { Zdolność do wykonywania ruchów } \\
\text { szybkich }\end{array}$} & \multicolumn{2}{|c|}{ Ręka prawa } & \multicolumn{2}{c|}{ Ręka lewa } \\
\cline { 2 - 5 } & Badanie I & Badanie II & Badanie I & Badanie II \\
\cline { 2 - 5 } & $\%$ & $\%$ & $\%$ & $\%$ \\
\hline Norma & 83,3 & 83,3 & 79,2 & 75,0 \\
\hline Opóźnienie roczne & 16,7 & 4,2 & 20,8 & 12,5 \\
\hline Przyspieszenie roczne & - & 12,5 & - & 12,5 \\
\hline Ogółem & 100,0 & 100,0 & 100,0 & 100,0 \\
\hline
\end{tabular}

Dane dotyczące oceny zdolności do wykonywania ruchów lewą ręką są niższe w porównaniu z oceną wyników tych samych zdolności wykonanych prawą ręką. W I badaniu normę stwierdzono u 79,2\% dzieci, opóźnienie roczne u 20,8\%, nie stwierdzono natomiast przyspieszenia. W badaniu II w normie rozwojowej mieściło się 75\% dzieci, opóźnienie roczne wykazało 12,5\% dzieci, a przyspieszenie roczne $-12,5 \%$.

$\mathrm{V}$ grupa ćwiczeń miała na celu sprawdzenie zdolności do wykonywania różnych ruchów jednocześnie, na przykład inne ruchy nogami, a inne rękami. Zadaniem dzieci było wykonywanie ruchów szybkich poprzez włożenie do pudełka 10 zapałek w czasie 20 sekund, posługując się jednocześnie obiema rękami. Wyniki prezentowane są $\mathrm{w}$ tabeli 6. Podczas badania I stwierdzono normę u wszystkich dzieci, czyli $100 \%$. W badaniu drugim normą wykazało się 58,3\% dzieci, zaś przyspieszeniem rocznym $-41,7 \%$ dzieci.

Tabela 6. Zdolność do wykonywania różnych ruchów jednocześnie

\begin{tabular}{|l|c|c|}
\hline \multirow{2}{*}{ Zdolność do wykonywania różnych ruchów jednocześnie } & Badanie I & Badanie II \\
\cline { 2 - 3 } & $\%$ & $\%$ \\
\hline Norma & 100,0 & 58,3 \\
\hline Opóźnienie roczne & - & - \\
\hline Przyspieszenie roczne & - & 41,7 \\
\hline Ogółem & 100,0 & 100,0 \\
\hline
\end{tabular}

Ostatnia grupa ćwiczeń, którą wykonały dzieci, miała pomóc stwierdzić, czy w badanej grupie występują przyruchy (synkinezje). Podczas próby dzieci miały za zadanie zgrzytać zębami - osoba badająca obserwowała, czy występują lub nie 
występują przy tym przyruchy. Podczas I badania normę, czyli brak przyruchów stwierdzono u $83,3 \%$ dzieci, a opóźnienie roczne u $16,4 \%$. W badaniu II normą wykazało się 70,8\% dzieci, a przyspieszeniem rocznym $29,2 \%$ dzieci; opóźnienia nie stwierdzono. W tabeli 7 zestawiono wyniki z wymienionych badań z I i II etapu.

Tabela 7. Występowanie lub niewystępowanie synkinezji

\begin{tabular}{|l|c|c|}
\hline \multirow{2}{*}{ Występowanie lub niewystępowanie przyruchów (synkinezji) } & Badanie I & Badanie II \\
\cline { 2 - 3 } & $\%$ & $\%$ \\
\hline Norma & 83,3 & 70,8 \\
\hline Opóźnienie roczne & 16,7 & - \\
\hline Przyspieszenie roczne & - & 29,2 \\
\hline Ogółem & 100,0 & 100,0 \\
\hline
\end{tabular}

\section{PODSUMOWANIE I WNIOSKI}

Przedstawione wyniki badań wskazały obszary grafomotoryczne, które dzieci już opanowały, czyli są w normie, a u niektórych stwierdzono przyspieszenie roczne lub dwuletnie. Pomiędzy wynikami, przeprowadzonymi w I i II badaniu, zauważono w każdej grupie ćwiczeń wzrost umiejętności dzieci, o czym świadczą ich wyższe wyniki. $Z$ drugiej zaś strony uzyskane wyniki badań są potwierdzeniem, informacją zwrotną dla nauczycieli, że stosowane przez nich metody pracy z dziećmi są efektywne. Niestety, wyniki badań pozwoliły zaobserwować niektóre rodzaje zaburzeń w rozwoju motorycznym dzieci w wieku 5 lat. W tym miejscu należy stwierdzić, że najsłabsze wyniki dzieci uzyskały wykonując ćwiczenie z I grupy, czyli w zakresie równowagi i koordynacji statycznej. Opóźnienie roczne stwierdzono w I etapie badań nawet u 29\% osób, a w II badaniu u 20\% badanych dzieci. Mimo zmniejszonych wskaźników procentowych w zakresie opóźnień w II badaniu, grupa dzieci licząca około 24 osób będzie wymagała wsparcia ze strony nauczycieli w zakresie kształtowania równowagi i koordynacji statycznej poprzez celowo zaplanowane ćwiczenia kształtujące wymienione umiejętności.

Drugi obszar, wymagający wsparcia ze strony nauczycieli, dotyczy koordynacji ruchów całego ciała. Część dzieci nie zrobiła poprawnie ćwiczeń polegających na wykonywaniu podskoków na prawej, a potem na lewej nodze wzdłuż linii. Opóźnienia roczne stwierdzono zarówno w I, jak i w II badaniu. 
Ćwiczenia z grupy IV sprawdzały zdolność do wykonywania ruchów szybkich ręką prawą i lewą. W tym obszarze stwierdzono także opóźnienia, zarówno przy wykonywaniu ruchów ręką prawą, jak i lewą. Przy czym większy odsetek dzieci ma opóźnienia roczne przy wykonywaniu ruchów lewą ręką.

W kontekście analizy wymienionych słabych obszarów należy zwrócić uwagę na mocne strony dzieci w poziomie grafomotorycznym, które zdiagnozowano poprzez realizację wymienionych badań. Najwyższe wyniki dzieci uzyskały wykonując ćwiczenia z grupy II, V i VI. W II grupie ćwiczeń, sprawdzającej poziom koordynacji ruchów rąk, nie stwierdzono opóźnień, wyniki większości dzieci były $\mathrm{w}$ normie, a u niektórych nawet zaobserwowano przyspieszenie roczne i dwuletnie, co dowodzi, że poziom koordynacji ruchów rąk jest na dobrym poziomie, nie ma niepokojącego obniżenia sprawności manualnych, przejawiającego się zbyt małą precyzją ruchów dłoni i palców.

Ćwiczenia V grupy, sprawdzające zdolność do wykonywania różnych ruchów jednocześnie, dzieci wykonały zadowalająco, wyniki mieszczą się w normie i u niektórych wskazują na przyspieszenie roczne. Podobnie ćwiczenia z VI grupy, sprawdzające występowanie lub niewystępowanie synkinezji, wypadły pozytywnie, u żadnego badanego dziecka nie stwierdzono przyruchów.

Podsumowując należy stwierdzić, że przeprowadzone badania pokazały zróżnicowany poziom rozwoju grafomotorycznego w badanej grupie dzieci. Zgromadzony materiał badań będzie przedmiotem głębszej analizy, szczególnie w odniesieniu do tych dzieci, których wyniki nie mieściły się w normie. Należy także zasugerować nauczycielom przeprowadzenie testu do diagnozy dysleksji autorstwa Marty Bogdanowicz, aby wykluczyć, ewentualnie potwierdzić, zjawisko dysleksji pod kątem dysgrafii (Bogdanowicz, 2003).

Zaobserwowane trudności w rozwoju grafomotoryki u niektórych dzieci 5-letnich z pewnością będą przedmiotem pogłębionej analizy. Ogólnopolskie badania w zakresie diagnozy ryzyka dysleksji i dysgrafii dzieci szkolnych pokazały, że 10-15\% z nich napotyka na trudności w uczeniu się pisania i czytania (Brzezińska, 2004; Kordas, 2004). W ostatnich kilkunastu latach zaobserwowano wzrastającą liczbę uczniów z ryzykiem dysleksji zgłaszanych do badań specjalistycznych. Zwiększa się przede wszystkim liczba dzieci w wieku 6-7 lat. Z europejskich badań należy wymienić badania prowadzone w Danii, Wielkiej Brytanii i Holandii. W Danii przebadano dzieci przedszkolne i uczniów klasy pierwszej w zakresie pisania, czytania i umiejętności fonologicznych. Dzieci, u których zdiagnozowano dysleksję, uzyskały ocenę fonologiczną na poziomie niższym w porównaniu do dzieci z wysokiego ryzyka (Dandache i in., 2014). W Holandii i Wielkiej Brytanii 
badania w zakresie pisania, czytania i podstawowych umiejętności kognitywnych przeprowadzono $\mathrm{w}$ odniesieniu do rodzin obciążonych ryzykiem dysleksji. Wyniki badań potwierdzają wysokie ryzyko dysleksji wśród dzieci z rodzin dyslektycznych (Gochh i in., 2014; van Bergen i in., 2012). W Polsce w ostatnich latach nie odnotowuje się tego kierunku badań, na co z pewnością należy zwrócić uwagę ze względu na potrzebę wczesnego podejmowania pracy terapeutycznej.

Planowanie dalszych działań wspomagających w stosunku do niektórych dzieci będzie $\mathrm{z}$ pewnością przedmiotem współpracy nauczycieli z rodzicami. Warto jeszcze raz podkreślić znaczenie pracy nauczycieli $\mathrm{z}$ dziećmi $\mathrm{w}$ zakresie rozwoju grafomotoryki, ich zaangażowanie, dobór odpowiednich ćwiczeń, które są nie do przecenienia, o czym dowodzą wyniki badań przeprowadzone po 6 miesiącach pracy w przedszkolach. Wyniki dzieci z II etapu badań z każdej grupy ćwiczeń pokazały tendencję wzrostową, co wskazuje na podniesienie ich rozwoju psychoruchowego, a w szczególności grafomotorycznego. Ma to również istotny wpływ na przyszłość badanej grupy dzieci, na ich gotowość szkolną, na poziom wyników, które będą osiągać jako uczniowie.

Mając na uwadze przedstawione wyniki badań, które zobrazowały tylko niektóre aspekty zagadnienia kształtowania umiejętności grafomotorycznych dzieci, należy zwrócić uwagę, że nie wyczerpują one w pełni tej części edukacji przedszkolnej dziecka, ale jedynie dostrzegają wagę problemu, który w przyszłości będzie kontynuowany.

\section{BIBLIOGRAFIA}

Bogdanowicz, M. (2009). Fakty, mity i kontrowersje wokół diagnozy dysleksji. W: G. KRAsowicz-KuPIS (red.), Diagnoza dysleksji. Najważniejsze problemy (s. 25-30). Gdańsk: Wydawnictwo Harmonia.

Bogdanowicz, M. (2003). Przygotowanie do nauki pisania. Ćwiczenia grafomotoryczne wedtug Hany Tymichovej. Gdańsk: Wydawnictwo Harmonia.

KoRDAS, K. (2004). Wykorzystanie Skali Ryzyka Dysleksji do diagnozy dzieci sześcioletnich w wybranych przedszkolach łomżyńskich. Łomża: BIP Urzędu Miejskiego w Łomży.

BRZEZIŃSKA, A. (2004). Ocena ryzyka dysleksji u dzieci w wieku przedszkolnym przez rodziców i jej uwarunkowania. Edukacja, 4, 39-54.

Cyran-Prus, M., Matych, E. (2004). Zaburzenia lateralizacji. W: E.M. Skorek (red.), Terapia pedagogiczna. Wybrane zagadnienia. T. 1. (s. 73-80). Kraków: Oficyna Wydawnicza „Impuls”.

DANDACHE, S., Wouters, J., GHESQuiÈre, P. (2014). Development of Reading and Phonological

Skills of Children at Family Risk for Dyslexia: A Longitudinal Analysis from Kindergarten to Sixth Grade. Dyslexia, 20, 305-329.

Dennison, P.E., Dennison, G. (2003). Kinezjologia edukacyjna dla dzieci. Wydawca: Międzynarodowy Instytut NeuroKinezjologii

DMochowsKA, M. (1991). Zanim dziecko zacznie pisać. Warszawa: WSiP. 
DZIAMSKA, D. (2010). Edukacja przez ruch. Kropki, kreski, owale, wiazki. Warszawa: WSiP.

Gooch, D., Hulme, Ch., Nash, H., Snowling, M.J. (2014). Comorbidities in Preschool Children at Family Risk of Dyslexia. Journal of Child Psychology and Psychiatry, 55(3), 237-246. DOI:10.1111/jcpp.12139.

GRUSZCZYK-KolCZYŃSKA, E., ZIELIŃSKA, E. (2009). Zajęcia dydaktyczno-wyrównawcze dla dzieci, które rozpoczna naukę w szkole. Warszawa: Wydawnictwo Edukacja Polska.

Klim-Klimaszewska, A. (2015). Praca z dzieckiem ryzyka dysleksji i dysgrafii na zajęciach terapeutycznych w przedszkolu. Warszawa: Wydawnictwo Erica.

Krasowicz-KuPIS, G. (2009). Psychologia dysleksji. Warszawa: PWN.

MAŃKOwSKA, I. (2005). Kreowanie rozwoju dziecka, kinezjologia edukacyjna i inne nowoczesne metody terapeutyczne w praktyce. Gdynia: Wydawnictwo Operon.

PRZEWEDA, R. (1981). Rozwój somatyczny i motoryczny. Warszawa: WSiP.

PUTYŃSKI, L. (1998). Skala Rozwoju Motorycznego Oziereckiego (Historia i współczesne zastosowania), Acta Universitatis Lodziensis Folia Psychologica, 2,145-149.

SAwA, B. (1980). Jeżeli dziecko źle czyta i pisze. Warszawa: WSiP.

SZYMAŃSKA, W. (2004). Trudności w uczeniu się uwarunkowane zaburzeniami spostrzeżeń wzrokowych. W: E.M. SKOREK (red.), Terapia pedagogiczna. Wybrane zagadnienia. T. 1. (s. 45-48). Kraków: Oficyna Wydawnicza „Impuls”.

WlaźNIK, K. (1996). Wychowanie fizyczne w przedszkolu. Przewodnik metodyczny dla nauczycieli. Warszawa: Wydawnictwo Juka.

Rozporządzenie Ministra Edukacji Narodowej z dnia 14 lutego 2017 r.w sprawie podstawy programowej wychowania przedszkolnego oraz podstawy programowej kształcenia ogólnego dla szkoły podstawowej, Dz. U. z dnia 24 lutego 2017 r., poz. 356.

\section{POZIOM ROZWOJU GRAFOMOTORYCZNEGO U DZIECI 5-LETNICH W ASPEKCIE GOTOWOŚCI DO PODJĘCIA NAUKI PISANIA}

\section{Streszczenie}

Pisanie zalicza się do podstawowych umiejętności gwarantujących dziecku uczenie się, dlatego ważne jest to, aby ta umiejętność przez dziecko została opanowana w najwyższym stopniu. W odniesieniu do nauki pisania specjaliści zwracają uwagę na potrzebę kształtowania sprawności manualnych, koordynację wzrokowo-ruchową, kształtowanie równowagi, opanowanie których zapewni dziecku osiągnięcie gotowości szkolnej. Wymienione umiejętności określa się pojęciem grafomotoryki. Dzieci, które w przyszłości mogą mieć problemy z nauką pisania, można dostrzec już w przedszkolu.

Dlatego celem podjętych badań było zdiagnozowanie poziomu rozwoju grafomotoryki u dzieci 5-letnich (120 osób) uczęszczających do kilku losowo wybranych przedszkoli w powiecie bialskim. Badania przeprowadzono za pomocą testu Oziereckiego przystosowanego do polskich potrzeb przez Aleksandra Barańskiego. Badania zrealizowano w dwóch etapach. Pierwszy etap przeprowadzono na początku roku szkolnego, drugi zaś po 6 miesiącach. Wyniki badań pokazały, z jednej strony, progres umiejętności grafomotorycznych u większości dzieci, a z drugiej, w niektórych przypadkach, potrzebę wsparcia w formie specjalistycznych zajęć terapeutycznych.

Słowa kluczowe: dziecko; grafomotoryka; rozwój dziecka; przedszkole; nauczyciel. 


\title{
THE LEVEL OF GRAPHOMOTOR DEVELOPMENT IN 5-YEAR-OLD CHILDREN IN LIGHT OF WRITING READINESS
}

\author{
S u m m a r y
}

Writing is one of the basics skills in the process of learning, thus it is of outmost importance for a child to master it to the best extent possible. As far as learning to write is concerned, specialists draw attention to the need to improve manual dexterity, visual-motor coordination, and the development of balance, the acquisition of which is to ensure the achievement of school readiness. The above mentioned skills are referred to as graphomotorics. Children who can have future problems with writing can already be identified in preschool.

Therefore, the purpose of the research was to diagnose the level of graphomotor skills development in 5-year-old children (120 preschoolers) attending randomly selected kindergartens in Biała Podlaska district. The research was performed by means of the Ozierecki test which was adapted to the needs of Polish research by Aleksander Barański. The research was conducted in two stages. The first one was performed at the beginning of the school year, and the second one was carried out after six months. On the one hand, the research findings indicated the development of graphomotor skills. However, in some cases, the need for therapeutic support was identified.

Key words: children; graphomotor skills; child development; preschools; teachers. 